\title{
Dietary management of hepatic encephalopathy in cirrhotic patients: survey of current practice in United Kingdom
}

\author{
Clare T Soulsby, Marsha Y Morgan
}

In the early 1950s it was shown that some patients with cirrhosis given "nitrogenous substances," including excess dietary protein, developed hepatic "precoma." These largely uncontrolled observations led to the introduction of dietary protein restriction to treat hepatic encephalopathy.

Recent research has shown, however, that protein requirements are increased in these patients, ${ }^{2}$ that high protein diets are well tolerated, and that their use, particularly in patients who are malnourished, is associated with sustained improvement in mental state. $^{34}$ In response, the European Society for Parenteral and Enteral Nutrition has recommended that traditional protein restriction should be abandoned in patients with hepatic encephalopathy particularly as other effective treatments are available. ${ }^{5}$ We undertook this survey to review the current dietary management of these patients in hospitals throughout the United Kingdom.

\section{Methods and results}

We devised and piloted a questionnaire and then sent it to the 110 UK dietetic departments approved by the British Dietetic Association for training student dietitians. Information was requested on the referral, clinical assessment, and dietary management of all inpatients with cirrhosis and hepatic encephalopathy seen in the past 12 months. The questionnaires were returned anonymously. Closed questions were analysed with descriptive statistics and open questions by content analysis.

Seventy one $(65 \%)$ questionnaires were returned; 64 departments with relevant experience provided details of the dietary management of 1046 patients. Overall, $759(73 \%)$ patients had had their protein intake restricted to some degree (table). In most of these patients the diets were imposed for prolonged periods because treatment end points were not specified or poorly defined. Over half of the responding departments reported requests to restrict protein prophylactically in cirrhotic patients who were neuropsychiatrically unimpaired.

Overall, $261(25 \%)$ patients were referred with a prescriptive request to restrict protein intake; the remaining 758 were referred with a request for dietary advice that allowed leeway for discussion. Nevertheless, the dietitians still felt that 153 (14\%) patients had had their protein intake restricted inappropriately (table).

Difficulties were experienced in maintaining oral intake in many of these patients; 58 (91\%) of the responding departments reported substantial problems because of anorexia, $17(27 \%)$ because patients were drowsy or confused, and $12(19 \%)$ because the diets were unpalatable. Nevertheless, less than $25 \%$ of

\begin{tabular}{lcc}
\hline $\begin{array}{l}\text { Dietary management of } 1046 \text { cirrhotic patients with hepatic } \\
\text { encephalopathy. Values are numbers (percentages) of patients } \\
\text { Dietitians' } \\
\text { preference }\end{array}$ \\
\begin{tabular}{lcc} 
Dietary protein intake (g/day) & Diet instituted & $440(42)$ \\
\hline Unrestricted & $287(27)$ & $499(48)$ \\
\hline Moderately restricted $(30-50)$ & $340(40)$ & $107(10)$ \\
\hline Seriously restricted $(<30)$ & 340
\end{tabular}
\end{tabular}

these patients received appropriate additional nutritional support.

\section{Comment}

This survey shows that despite clear recommendations to the contrary, ${ }^{5}$ most patients in the United Kingdom with cirrhosis and hepatic encephalopathy have their protein intake restricted, often for prolonged periods. Protein restriction is also widespread in patients thought to be at risk of developing hepatic encephalopathy, which has no justification. Many of these patients are anorexic and find the diets unpalatable and hence unacceptable, yet few are given appropriate nutritional support. In general, dietitians are less in favour of restricting protein intake than the referring doctors, but either their views are not expressed or their advice is not heeded.

The widespread inappropriate dietary management of cirrhotic patients with hepatic encephalopathy is likely to adversely affect outcome. Both dietitians and medical practitioners need to be made aware of recent guidelines, ${ }^{5}$ to change current practice, and to work together effectively.

We thank the participating dietitians for completing the questionnaires.

Contributors: CTS initiated the study, designed the original questionnaire, undertook the field work, analysed the data, assisted in writing the paper, and secured the funding. MYM refined the design of the study and the questionnaire, participated in the data analysis, wrote the paper, and is the guarantor.

Funding: The study was partly funded by the British Dietetic Association.

Conflict of interest: None.

1 Phillips GB, Schwartz R, Gabuzda GJ Jr, Davidson CS. The syndrome of impending hepatic coma in patients with cirrhosis of the liver given certain nitrogenous substances. N Engl J Med 1952;247:239-6.

2 Nielsen K, Kondrup J, Martinsen L, Døssing H, Larsson B, Stilling B, et al. Long-term oral refeeding of patients with cirrhosis of the liver. Br J Nutr 1995;74:557-67.

3 Kearns PJ, Young H, Garcia G, Blaschke T, O'Hanlon G, Rinki M, et al. Accelerated improvement of alcoholic liver disease with enteral nutrition. Gastroenterology 1992;102:200-5.

4 Morgan TR, Moritz TE, Mendenhall CL, Haas R, and VA Cooperative Study Group \#275. Protein consumption and hepatic encephalopathy in alcoholic hepatitis. J Am Coll Nutr 1995;14:152-8.

5 Plauth M, Merli M, Kondrup J, Weimann A, Ferenci P, Müller MJ, ESPEN Consensus Group. ESPEN guidelines for nutrition in liver disease and transplantation. Clin Nutr 1997;16:43-55.

(Accepted 27 August 1998)
Editorial

by Seymour

Department of

Nutrition and

Dietetics, Royal Free

Hospital, London

NW3 2QG

Clare T Soulsby, senior dietitian

University

Department of

Medicine, Royal

Free Hospital and

School of Medicine

London NW3 2QG

Marsha Y Morgan,

senior lecturer in

medicine

Correspondence to: Dr Morgan

BMJ 1999;318:1391 